\title{
БИОЧИПЫ В ДИАГНОСТИКЕ АУТОИММУННЫХ ПОЛИГЛАНДУЛЯРНЫХ СИНДРОМОВ
}

\author{
'Савватеева Е.Н., ${ }^{2}$ Юкина М.Ю., ${ }^{2}$ Нуралиева Н.Ф., 'Филиппова М.А., 'Грядунов Д.А., ${ }^{1}$ Трошина Е.А. \\ 'Федеральное государственное бюджетное учреждение науки Институт молекулярной биологии \\ им. В.А. Энгельгардта Российской академии наук (ИМБ РАН) \\ 2Федеральное государственное бюджетное учреждение «Национальный медицинский исследовательский \\ иентр эндокринологии» Министерства здравоохранения Российской Федерации (ФГБУ «НМИЦ эндокринологии» \\ Минздрава России)
}

Разработан метод мультиплексного иммуноанализа на основе гидрогелевого биочипа для обнаружения в сыворотке крови антител, характерных для аутоиммунных полигландулярных синдромов (АПС), включая органоспецифичные аутоантитела (21-OH, GAD-65, ICA, IA2, Tg, TPO), аутоантитела к интерферонам (IFN- $\omega$, IFN-a-2a) и интерлейкину IL-22. Проведена апробация созданного метода с использованием 206 образцов сыворотки крови от пациентов с диагностированными АПС-1 ( $n=18)$, AПС-2 ( $n=39)$, изолированными аутоиммунными эндокринными патологиями $(\mathrm{n}=50)$, неаутоиммунными эндокринными патологиями $(\mathrm{n}=70)$, условно здоровых доноров $(\mathrm{n}=28)$. Показано, что для AПС-1 характерно наличие по крайней мере двух специфических аутоантител к цитокинам, при этом у 16 из 18 пациентов с АПС-1 был выявлен характерный триплет аутоантител (IFN- $\omega$ + IFN-a-2a + IL-22). Специфичность и чувствительность метода для скрининга АПС-1 в данной выборке составили 99,5\% и 100\%. Совпадение результатов, полученных на биочипе, с методом ИФА при выявлении органоспецифичных аутоантител (21-OH, GAD-65, ICA, IA2, $\mathrm{Tg}$, TPO) у пациентов как с изолированными, так и с множественными эндокринопатиями, составило от $89,9 \%$ до 97,6\%. Разработанный метод может быть использован в качестве дополнительного инструмента на первом этапе обследования пациентов с множественными и изолированными аутоиммунными эндокринопатиями. 